Authors' copy. Frade, C. \& Pyyhtinen, O. Weber and Simmel's philosophical and political stances: A dialogue in three acts. Journal of Classical Sociology. 2017, Vol. 17(2), pp. 87-100. @ The Author(s) 2017. DOI: http://dx.doi.org/10.1177/1468795X17693437 . Reprinted by permission of SAGE Publications.

\title{
Weber and Simmel's philosophical and political stances: A dialogue in three acts
}

\author{
Carlos Frade \& Olli Pyyhtinen \\ Published in Journal of Classical Sociology, 17(2): 87-100.
}

\begin{abstract}
This article is an imagined dialogue between Weber and Simmel which makes a modest use of some of the resources of theatrical play in order to provide an overall portrait of both thinkers and to bring their thought to bear on our present. The dialogue consists of three acts focused on three central problematics in as many critical moments in Weber and Simmel's lives: Act I takes place during the preparations for the first conference of the German Sociological Association and thus deals with the constitution of sociology as a socio-cultural science. Act II takes place amid the First World War and its theme is evidently politics. Finally, Act III, where our two characters correspond instead of maintaining a face-to-face dialogue, is situated towards the end of the war and focuses on the attitude to life and indeed to death, as Simmel's tragic yet admirable death takes place then. A brief introduction explains how we tried to use the possibilities of the dialogical form to expound Weber's and Simmel's thought, to compel them to confront their own blind spots and 'unthoughts', as well as to explore new ways of teaching the classics and transmitting their thought.
\end{abstract}

\section{Keywords}

Attitude to life, imperialism, nationalism, philosophy, politics, revolution, social science, sociological reasoning, transmission method, war

\section{Introduction}

This is an imagined dialogue between Weber and Simmel in which we seek to honour the remit of the Edinburgh conference for which the dialogue was prepared and where it was read-performed by the authors for the first time (Frade as Weber, Pyyhtinen as Simmel), namely, not only to bring Weber's and Simmel's thought to life, but to bring that thought to bear on our present. To achieve this, we were clear that there were at least three conditions, both negative and positive, we had to try and meet:

First, the dialogue had to be truly addressed to all, and thus to anyone, and not specifically to scholars; above all, it had to avoid scholasticism. 
Second, we had to stay away from a merely historical dialogue which would wallow in and thus somehow endorse the canonical figures of Weber and Simmel as these have been established for nearly one century now by a very prolific scholarship, and try instead to bring their thought to life, a task that required to enliven their own relation by divesting it of the social conventions which, particularly on Weber's side, prevented it from becoming a more fluid and fruitful exchange. In doing this, we deliberately contradict the historical record, which shows that Simmel was not among the very tiny circle of people whom Weber addressed by their first names. However, we must emphasize that the relation they maintain in the dialogue, where they address each other in a familiar manner as friends, is real - and the real is a category not to be confused with reality. It is that real, a relation free from formalities and conventionalisms, what enabled us to unfold and harness the possibilities of the theatrical form for developing a dialogical dynamics traversed by antagonisms from beginning to end. Through such antagonistic dialectic, we sought to compel our Weber and Simmel characters to confront not only what somehow goes without saying: their opposite stances. But beyond that, we especially wanted to have them face up to their own blind spots and 'unthoughts'.

Third, and finally, there is the fundamental question concerning the teaching of the classics and the transmission of their thought. While this aspect is already fully implicated in the aforementioned two conditions, we would like to highlight here that nodal point where the educational and the theatrical meet, namely, play. Two things were to be avoided as much as possible at this level: didacticism and entertainment - didacticism because it implies a managerial conception and practice of education as extrinsic to the matter at hand which technifies problems and ruins thought and the possibility of its transmission; entertainment because, as the ideological practice of pleasing opinions and the present state of things, it deactivates thought and stifles the possibility that the dialogical form brings about a subjective shift in the readerspectator. Thus, if education is inherent to the dialogue itself, it comes about as an effect of the play - assuming it is played in all seriousness, as children do.

As regards the questions and problematics addressed, our choice was determined by our intention to provide an overall conceptual portrait of both thinkers and play out the antagonisms of their thought through an imagined, but real, dialogue. Thus, we decided to focus on three central problematics in as many critical moments 
in Weber and Simmel's lives: Act I takes place during the preparations for the first conference of the German Sociological Association and thus deals with the constitution of sociology as a socio-cultural science. Act II takes place amid World War 1 and its theme is evidently politics. Finally, Act III, where our two characters correspond instead of maintaining a face-to-face dialogue, is situated towards the end of the war and focuses on the attitude to life and indeed to death, as Simmel's tragic yet admirable death occurs at the end of the dialogue.

\section{Dialogue}

ACT I: Spring 1910, preparations for the first conference of the German Sociological Association (Deutsche Gesellschaft für Soziologie; DGS), which will be finally held on 19/22 October 1910, in Frankfurt. Simmel's apartment in Berlin. Topic: Nature of sociological work as both theory and practice.

Weber: What astonishes me, Dr Simmel, is that ... we are so different animals. Indeed so opposite and antagonistic are our ultimate positions that ... it is as if we were from different species. And yet, ... yet we are able to connect and to communicate pretty much ... I may object to your peculiar 'style' of doing sociological work, to a way of reasoning that to me is a way of reasoning 'by analogy' ... but you do all this so brilliantly, ...

Simmel: $\quad$ Max, please: Georg, not Simmel - but Georg! For reasons that have escaped me my work has found many fierce adversaries in Germany, enemies, even - as we both know all too well from the disappointing result of my appointment at Heidelberg.

Weber: I find that deeply regrettable myself, too. And I'm sorry that all my own efforts to secure you a position were in vain.

Simmel: $\quad$ Please be assured that I appreciate your help and support. Nevertheless, it gives me little comfort to realize that even the ones to whom my appointment would have been scandalous, appreciate the 'great attraction' that I would have been for the university; they just don't love me there. In certain circles there prevails the idea that I'm an 'exclusively critical, even destructive spirit', and these foolish detractors also claim that 
my thinking only leads to negation. What nonsense! In my writings just as much in my teaching, ... I always tend toward the positive, ultimately toward gaining a deeper understanding of the totality of the world. That should be clear to anyone who is the least familiar with my work. And, my use of analogies that you lamented for

Weber: $\quad$... yes, Georg, but ...

Simmel: $\quad . .$. but for me, through analogies we are able to make surprising links between seemingly unconnected and distinct things. I see analogies as means of grasping the unfamiliar in terms of the familiar. They allow us to comprehend what we do not know by relating it to what we already know.

Weber: But you use them to illustrate utterly heterogeneous matters, and I cannot accept that. Such whims of mind, no matter how stimulating, are not much of a methodology!

Simmel: Heterogeneity is bad only as long as you are trying to build a unified system. To me, the further the subject matters lie from each other, the more extensive is our glimpse of the totality. To propose an analogy between, say, sociability and art - I think I have mentioned you that I'm planning on discussing sociability in my opening address to our conference, right? - is to highlight their similarity, to draw attention to what they have in common despite their differences. Analogies are about seeing similarity in difference.

What is more, let me note that by using analogies I do not only try to make graspable something new or less familiar by comparing it to the more familiar, but I am at the same time trying to discover something new in the familiar as well, I mean see the familiar in a new light. Thanks to the relation of analogy established, we are able to see both of the related terms from a new perspective.

Weber: Yes, Georg, I understand. But look: yours is a mode of perception and a manner of expression which are unique. It is truly brilliant what you do, and your phenomenological capture of modern 
man's experience is extremely sensitive and provides a wealth of stimulation. But this is something inherent in your personality, something nobody can imitate. And this is the problem, Georg; I am concerned with the question of transmission or transmissibility, with education if you wish. Transmission requires method, ultimately an impersonal method, which is what makes knowledge independent of the personality of the thinker, and thus potentially transmissible. Without this sense of method in the broad sense we cannot possibly establish a new discipline or a new science. You have mentioned our approaching conference in October, and here the main problem is how to develop the new socio-cultural science we both consider sociology to be.

Simmel: You are right, Max, my own sociology is of a very particular kind. And it's true that it has no other exponents in Germany other than myself, and also in that sense it is a mode of thinking, a specific form of questioning rather than a discipline. However, while it's likely that I will remain without true disciples and followers, to me thinking - including my own - is never reducible to the thinking person (nor to her environment, for that matter). Rather, it has its roots in the layer of typical spirituality to be found in the thinker and their thought. The singular type of each thinker mediates the relation between the particular and the general; thinking turns the personal into something objective, and the objective into something personal. So, I hope that my own work, too, is able to stand for something typical or general that coincides with how others experience the world.

Weber: That's well put, Georg, and very few will be able to claim such power of intellectual stimulation as I am sure you will have among the future generations. But now our problem is different. We have devoted so many efforts to our Sociological Association and to prepare our approaching first conference! I wouldn't like all this to be wasted, so we need to continue to work this out together. And here we have the notion of 
culture at the centre of our concerns. You yourself conceive of culture in terms of tensions; culture for you is what comes out of the continuous conflicts and contradictions between subjective life and objective form. This is what I find most productive in your approach (and this not only on account of the obvious affinities with my own ideas about the primacy of the question of tensions and conflicts).

Simmel: $\quad$ Yes, your interpretation is apt. For me culture involves the creation and assimilation of something that's external to the human subject. We develop ourselves by developing objects. However, once created those objects tend to gain autonomy, a logic and lawfulness of their own. So in that sense, yes, it all comes down to conflict - that between life and form. I see their contrast as the innermost motive for cultural transformation and the basis for culture having a history. And, just like any cultural forms, social forms, too, may gain independence of the life and culture of subjects.

We can see this objectification happening throughout the whole range of social forms, to some extent even in the elementary forms that mostly remain in the servitude of the practical needs of daily life, but especially in the larger institutionalized formations, such as family structures, the state, religion and in particular the economy. Indeed, perhaps no other form has truly become a world for itself to the extent that the economy has. It seems to operate completely without regard for what the subjects need and want. The economy now goes its necessary way, entirely as though men were there for its sake, but not it for the sake of man. So, in the economy, the tension and conflict between life and what is opposite-of-life reaches its culmination.

All in all, for me the deepest problems of modern life have to do with how human subjects are able to maintain the independence and individuality of their existence against the constraining coercive power of autonomous, objectified forms such as society and its sovereign powers. So, while we most certainly need to discuss in our conference 
the field of sociology and its methodological justification and its relation to its neighbouring fields, I think, Max, that we also need to address social and cultural phenomena in the widest possible sense to avoid getting stuck with formal and scholastic disputes.

Weber: Precisely. It is on that basis that I think we have to try and define a form of enquiry adequate to the understanding of sociology as socio-cultural science, aimed at studying the external, shaping effects of objective forms, above all of that most fateful force of our modern life, and then look at their significance for subjective and cultural life.

Simmel: I see. What I find at the core of cultural processes today is a growing separation, in truth a gap between objective culture and subjective culture. And in this context it seems to me to be of utmost importance to enquire about how individuality can persist and flourish in the face of the overwhelmingly 'external culture and technique of life', or the 'social-technological mechanism'.

Weber: That's our fate, confronting those growing gaps while living within the 'social-technological mechanism' or what I call 'the steel-hard shell'. The subjective capacity to wage this struggle, which preoccupies me deeply, is at the core of what I once called the 'transcendental presupposition of every science of culture' and should also be a major research aim of the kind of sociology we want to foster (you know, 'man as a cultural being able to take a stance toward the world and to lend it meaning'); this is not simply a question of acting in relation to values, which is trivial, let alone, as some have claimed, of having preferences ... 'having preferences!' [W repeats disdainfully], those are the last men! [big laughter] - perhaps they would wish to establish a socio-cultural science of happiness. Those of whom all that can be said is that they have preferences are men whose life simply slips by, exposed to the pushing and pulling forces of the world. But this has nothing to do with what I meant, which is a question of subjective life conduct, and thus of subjective capacity to lead an inwardly conducted life. Of course such 
capacity is fostered or stifled by socio-cultural forms and institutions, and that's why I am determined to propose to our Association in the October meeting to begin with two major sociological enquiries, one on 'associational life' and another one on the cultural significance of the modern press.

Simmel: I share your view. The socio-historical relations most certainly create possibilities and intensities for the emergence and development of individuality: the impersonal life of the metropolis demands of subjects that they develop and stress personal uniqueness. In fact, ... I think that we are able to understand those aspects of modern life which make it 'modern' only by analysing the adaptation of individuals to social conditions, to objective culture and its forces that lie outside individual subjects. However, at the same time I see that it's important to emphasize that the life of the individual is not exhausted by the socio-historical milieu. The individual self not only belongs to the world as a part but is also a self-enclosed whole, ... indeed a world in itself.

Weber: I don't think I share your view of what you call 'qualitative individuality', especially the way I know you romanticize the heroic individuality of your cultural idols such as Michelangelo and Rembrandt. So also in the approaching conference I intend to kindle some controversy and discord in this regard in relation to you, Georg. But even more generally, creating controversy and disagreement is always useful to clarify problems and make our positions manifest - and then, once this is clarified, we can decide whether to continue the dispute among ourselves or to displace it toward other fronts. A discipline which is alive is surely driven by some substantive controversies on the serious problems.

Simmel: I for my part feel that it will serve the aims of our conference the best if we delineate sociology in a very broad sense, along the lines how we specified it in the invitation to the Sociological Association that we sent out to colleagues. We should not let disputes, tensions and quarrels 
within the discipline take hold of us, for that might hamper our goal to secure sociology a place in the family of sciences - mind you, ... to this day there is not a single chair in sociology in the whole of Germany! But of course, as you very well know, Max, personally I take controversies as very productive for thought. Instead of making a final choice between opposing viewpoints or adopting a half-hearted mediation, I always think that we need to proceed through infinite reciprocity, that is, base our analysis on a shifting balance between the poles of the contrast.

\section{[END OF ACT I]}

ACT II: Winter 1917-1918, amid the war and the fading enthusiasm for it. Weber had been elected to the Workers' and Soldiers' Council of Heidelberg, and the bourgeois world was under the shock of October 1917 and its intense reverberations in Germany before the Spartacist revolution broke out. The dialogue takes place during Simmel's imagined visit to Weber's house in Heidelberg (famous for its Sunday afternoon intellectual gatherings) from his retreat in the Black Forest, where he was enjoying the joys of crispy mountain air and quiet existence. Topic: politics (war, nationalism, imperialism, masses, revolution).

Weber: We cannot deny that we both happily shared the national enthusiasm that took the country by storm in the summer of 1914. It is now more than three years ago. We were fascinated and deeply affected, yes ... we experienced joy, that preserve of rare collective moments and of the highest intellectual achievements. Indeed we were carried away by the massive willingness we saw and felt (at least I did) to sacrifice one's life. Perhaps things now look different [W pauses for a moment, reflectively]: the war that then seemed 'great and wonderful' now is senseless, transformed as it is in the everyday.

Simmel: $\quad$ My dear Max, we were certainly carried away. I remember well how I thought that the war would bring about an altogether new time, one that broke with prevailing cynicism and did away 
with the aestheticisation of existence and with mammonism. This did happen then, I believe. ... But I also believed that the war, ... that the welcoming of war in that mood of joy you mentioned amounted to a transcending of individual and class interests - a very mistaken judgement in retrospect.

Weber: Mistaken? Well, not everything, Georg, surely not for me. I felt and still feel with the same conviction that that sense of national unity, that patriotic enthusiasm and the willingness to go to the very end and risk one's life for the fatherland has permanent value - it makes sense to me, Georg, as something meaningful and lasting ... to the point (I hadn't told this to you before, so I 'confess' now) that I went back to my Intermediate Reflection ...

Simmel: Oh, so you went back to what is without doubt one of your greatest intellectual achievements? To change something!

Weber: Yes, I went back to sharpen the idea about what a meaningful death could be for us, members of modern humankind, and to make clear that only 'perishing in the calling', if anything, can make death meaningful for us. This total devotion to the calling, assuming we have one, my dear Georg, rather than (as you would have it) an endless quest for a vague unity with life, which to me borders on the mystical escape, is what can have eternal value. Provided of course that we are committed to it on an everyday basis; and then we find joy in it. You see, Georg, I am proud to say that the joy we felt in the summer of 1914 I have experienced many times since - and this in spite of all the dreadful things that have happened in all these years of war, in spite of my restlessness and constant tension and anger at the incompetence of our leaders; yes in spite of all that, and in the midst of all that, I have found true moments of joy when talking to the returning soldiers, or welcoming wounded soldier-friends here in this house and listening to their rather different stories and views, ... and also of course in my frequent disputes with the revolutionary youth (that immature youth but beautiful and 
admirable after all) ... Yes, all this has been extraordinary and a source of joy for me. So, yes, what we felt in 1914, I meant it and I mean it till the end.

Simmel: $\quad$ Now this is you - the Max Weber whom I know. As for me, well, you know very well that I am 'politically unmusical', as you would say. But I felt as if the war took hold of everything. Indeed, I experienced it as the 'absolute situation', irresistible and somehow beyond comprehension, even. You may say that I succumbed to it, but in truth I willingly submitted to it as a lifetransforming force. At any rate, you will be glad to hear that I have continued with my work, in which I am very absorbed now.

Weber: Glad but not surprised, Georg; that's your calling and you're faithful to it.

Simmel: Yes, this has never been in question. But the years I have spent in Strasbourg have had the effect of aging me twice or three times over what is normal. During the war academic activity has equalled zero there. Apart from few wonderful exceptions the faculty as a whole is, frankly, a half-witted bunch. Most locals remain strangers and mentally distant to me and Gertrud. In Strasbourg I often have the feeling that the inner excitation of pursuing my work as well as the monstrous tensions brought by the war find no counterpart in the dull and monotonous course of everyday life, as if one had to endure disjointed temporalities. So hard these war years have been and still are, hmmm ... this is something I cannot make sense of, or even fully express. But I suspect that you think of me as incompetent or a cretin in politics who has to be taken to the political kindergarten ...

Weber: Unmusical in politics, Georg - only that, you said it.

Simmel: $\quad$ Yes, yes. I love Germany, the German Spirit, and I wanted to make clear where my side was. It is true that I did not think, that I left unthought many things in that love. But I believe I am not the only one who carries many 'unthoughts' to his ultimate commitments, as you will say, and has nevertheless gone on with them, without 
thinking such unthoughts through and yet indulging in the expectation or hope that something, something short of a miracle, may happen. Isn't this the conclusion to be directly drawn from what you were telling me a while ago, after I arrived, in relation to your discussions in the last months with our common friend $\mathrm{Dr}$ Lukács, whom you've always treated not only as a privileged intellect but also as one of your favourite companions in conversation? The impression I got from your words - and those were weighty words, Max, spontaneous and heartfelt words, words reflecting something that seems to disturb you deeply - my impression was that you felt hard pressed to account for your nationalist and imperialist politics ...

Weber: $\quad$... You know that the questions of how we should imagine peace and the kind of peace that was to result from this war were always at the heart of my concerns and my public interventions - were and are, today even more so. This makes my position radically different from the blind imperialism of the Pan-German league and the military command ...

Simmel: $\quad$... whom I know you are publicly fighting with your usual brio and courage. But perhaps the difference between blind and well-advised imperialism is ultimately not as radical as you imply. At any rate, the question that seems to arise from what you said about your disputes with Lukács is that the way you often dismiss the revolution (not that you reject it personally, but that you dismiss it intellectually) may be inconsistent with your defence of nationalism or national imperialism. After all, nearly all your disqualifications of the revolutionary drive can equally be applied to the imperialist drive: I mean, you indict the revolutionary for ideological fanaticism, but you can be indicted for nationalistic fanaticism; you mock the romanticism of the general strike, but one can also deride the romanticism of the national idea; you dismiss revolutionary expectations, but one can also dismiss imperialistic expectations; and, finally, you argue that the revolution is often 
attempted at the expense of the proletariat, but you can be told that imperialistic expansion has been attempted at the expense of the German people - after all, if one pauses for a moment to reflect on the many hundreds of thousands who have died so far ... For God's sake, Max, is this a war or is it senseless butchery?

Weber: $\quad .$. Yes, ... it has become a senseless slaughter; this cannot be denied. Nor can I deny to you that the issue you pose troubles me. But look, Georg, I was referring before to the moments of joy I have felt through these fateful years ... They all bear on my relation with normal people, with ordinary fellows, indeed it is not just a relation, it is about working and getting things done with the modest people, including the revolutionaries - to tell you the truth, I have been surprised to find that not all of them are revolutionary 'literati', by no means; most are people of genuine conviction, true revolutionaries, I guess. My respect and admiration for all these people, revolutionaries or not, is unconditional.

Simmel: But that's the point, Max, your respect for them is sincere and unconditional, but on the other hand you decry what you often call 'the politics of the street'.... Isn't there something unthought in that relationship?

Weber: Politics needs leaders, Georg, if there are capable leaders then the irrationality of the street is removed, or at least is kept under control, so that we have something like the conduct of politics.

Simmel: I see. That's Max, the political animal we all know. But what about the revolutionary and the nationalist animals?

Weber: Well, here we enter into the battle of the gods, the eternal struggle between irreconcilable gods - a struggle that ultimately ... is undecidable, ...

Simmel: $\quad .$. Yes, but this cannot be the end of the story, Max

Weber: The end of the story or not, I cannot go further in thought, Georg, because there is no rational way of reconciling those terrible gods. At this point one has to choose, and in choosing, assume the consequences, for the choice is by no means the innocuous choice those so-called pluralist have 
pretended. Not at all, for in choosing and being consequent (if one truly chooses instead of simply going along with adaptations and accommodations to all sorts of things), one serves a god, which inevitably means that one offends all others. There are no middle-ways if one truly chooses. Otherwise, if one only pretends to choose, what we have is the usual non-committal game of adaptations and accommodations. It is an 'either-or', Georg. And I made my choice.

Simmel: Well, whether either-or, or all or nothing at all, I think I made mine too.

\section{[END OF ACT II]}

ACT III: Spring 1918 and September 1918, two (imagined) letters by Simmel and Weber to each other. Simmel, as his end is approaching, is almost entirely preoccupied with completing his Lebensanschauung and looks back at this life. Simmel and Weber touch again the issue of politics and reflect on philosophy and their stances to life.

An imagined letter by Georg Simmel to Max Weber (Black Forest, 21 March 1918).

Dear friend,

Please don't say that all I'm sending you nowadays is signed postcards - that is not true, and here's a letter to prove it! We are now back to the Württembergian Black Forest, in fresh, crisp air, surrounded by the smell of trees and by peaceful fields, enjoying lavish meals. The Christian opposition of flesh and spirit does not apply to me at all - if I lack in flesh, I also lack in spirit. This serenity and quietness suggests a calm, simple existence. It could be healing and full of hope, were it not for the violent world that continues to inject its toxics into one's blood.

I've also been working fervently. Recently I've been preoccupied by most difficult ethical and metaphysical studies. The latter I already take up in my book Rembrandt. I remember that in one of our discussions at your house (by the way I cherish the many long hours that we've sat at the tea table in your living room engaged in the art of lively conversation), I mean you once lamented that I saw war as life's solution to the crisis and tragedy of culture. And that may indeed have been the case back then, at the outbreak of the war. I must admit it, like so many other 
intellectuals I, too, was perhaps overly enthusiastic about the war and its possible outcomes. Now, in my Rembrandt book as well as in the manuscript that I am hastening to complete right now, lifephilosophy is stripped of politics. To me, life is essentially not a Kampfbegriff, but a metaphysical concept. To be sure, the concept of life is bound to remain somewhat vague and logically imprecise, as to succeed in defining it would be to deny life of its essence. Nevertheless, the notion now seems to permeate a multitude of spheres and is giving a more unified rhythm to their heartbeat, so to speak. For me, life is an emblem of movement and becoming - it never is; it's always becoming. This we find also in, say, Bergson. However, as he considers only creativity and how life constantly strives for more-life, I do not find in (Bergson's) vitalism a bridge that would connect flux and fixity. Life is no unbound flux without boundaries. On the contrary, we can encounter and know life only in some form, never as an absolute flow. And yet, life cannot be fully accommodated in form since forms funnel and dam its stream, and this is why life ceaselessly destroys old forms and creates new ones. So, from where does the striving towards more-life gain its impetus? you might ask, my friend - From boundaries that restrict life. Every current form of life presents such a boundary. Therefore, as I see it, we must ultimately understand life in terms of transgression. In life, the act of transcending boundaries and setting up boundaries are united: each step over a boundary also finds and creates a new one - life is at once more-life and more-than life. To me, this forms our human condition. We are boundary beings who have no boundaries.

And I see that philosophy comes to embody this to the fullest. Philosophy is a borderline activity that could perhaps be visualized by the image of the door. As it marks off a limited space, the door is a threshold, a borderline which demarcates an 'inside' from the 'outside'. However, just as the door gives shape to our limitedness, the fact that it can be opened illustrates the possibility at any moment of stepping out of this limitation into freedom. Philosophy likewise not only affirms our limitedness by uncovering what our thinking not-knowingly assumes, but it also surpasses our limits and opens up new possibilities of thinking and living, possibilities to think and live otherwise.

Please give my best to Marianne.

Yours,

Georg

An imagined letter by Weber to Simmel (Vienna, early April 1918).

Dear friend, 
Many thanks for your letter - you're right, no signed postcard this time. You refer to politics, if only somehow negatively, as you let me know that you have stripped your life-philosophy of a political mission - but I wonder, Georg, whether it ever had one! What I see as important is your explicit determination to treat life as a metaphysical concept and not as Kampfbegriff. In taking this path you know that there is no way back; this definitely distances you from Nietzsche, but it gets you closer, it seems to me, to your inner being and is much more attuned to your longing. I already can see this path being developed quite consistently, and I look forward to seeing your manuscript published soon.

As for me, I am aloof from politics. Being in Vienna helps me immensely to gain distance. Because, if I were home, I would have to leap into the fray, which I will have to do one day anyway, perhaps sooner than I expect, but for this I need to regain that distance - otherwise one gets easily trapped in this madhouse that Berlin has become.

You refer to our last conversation in Heidelberg - a memorable one, Georg, I cannot but concur with you - about the question of war. I think our stands are radically different, Georg, and they will remain so. You are bound, as practically all life-philosophies are, to a metaphysical monism that prevents you from making a real choice, or rather for which choice is simply out of the question. The war as an 'absolute situation' is the form that monism took for you when the war began; before this you were as unconcerned with politics as one can possibly be, and then you were taken over and truly overwhelmed by the war. In this situation there can be no choice, only successive forms of monism - or, in current philosophical parlance, different figures of the One.

With my warmest regards to Gertrud and to you Max

A (partly imagined) letter by Georg Simmel to Max and Marianne Weber.

Strasbourg, 15 September 1918, dictated to Gertrud Simmel. Dear Max Weber, dear Mrs. Marianne!

I thank you for your kind words and wishes. However, they cannot come true. I am a mortally ill man - I have liver cancer, and the doctors have given me only a couple of weeks to live. At any rate it would show extraordinary cruelty of God if this agony still lasted for months. So, these greetings need not be our last, but I count on the fact that they are, since my bodily and spiritual strength are 
exhausted. But I would like my friends to know that I do not feel my life being thus prematurely disrupted; I depart with the feeling that this is just right, just as it should be. Overall, death is not a violent interruption of life that would befall it as if from outside, but life needs, from itself, death as its opposite, as its other. And my life is complete now. I have delivered the manuscript of my last and final book Lebensanschauung; a book that is my philosophical testament, my deepest and most mature book, and very close to my heart. It will hopefully come out soon. The world has given me and I have given back to the world as much as I have been able to give. When it comes to my work, no further addition could have brought anything more to it substantially, and thus I am only lucky to avoid the slow decay of old age - I leave at the right moment without melancholy or resignation. Even in my present miserable state I feel I'm God's favourite, and despite all the neglect, sorrow and hardship I am deeply grateful that I've been able to live my life the way I have and that this is how it will finally come to its end. Please think of me as someone who said goodbye with his head up. And be warmly thanked for all the friendship and love that you have given me. As long as I breathe I will regard you two as a great gift to my life and as long as I live I will also respond to you.

Yours,

Georg Simmel

An imagined, never sent farewell letter by Weber to Simmel (early October 1918).

My dearest friend,

Your last letter has touched me profoundly. To see you facing death in such a serene and peaceful manner, and yet with such bravery and courage ... has struck my deepest chords. And now that I've just learnt that you have departed, that you are gone with such greatness of mind and soul, with your head up and your heart grateful, ... What can I do, since I am almost speechless and can hardly utter words that would seem appropriate? But I have to, because your exceptional way of dying testifies to your extraordinary way of living - how right the stoics were! But not only the stoics, whose philosophy your admirable death brings back to life; the ancient wisdom about a beautiful death is also awakened in a renewed form from its mythical past.

In truth your whole thought and your very life, my dearest Georg, are not strange to any momentous encounter between life and thought, connected as they are in multifarious ways to the major philosophical currents, ancient and modern, to the grand mystical and religious traditions that our world has seen, and 
certainly to the future. Your philosophy seems to me particularly attuned to assist the future strivings of philosophical life to find the beat of its pulse, and I have no doubts that it will be a major source of inspiration and a constant stimulation for generations to come.

Here things are getting worse by the day: the nation is definitely collapsing and communism has become a growing presence that may explode at any moment. The only possible source of hope, if there can be any at all, is the youth, the revolutionary and pacifist youth. Even if they are immature and often intoxicated with the romanticism of revolution, they are the only ones inwardly alive, while all I can see among the decent elders with whom I talk regularly is calculations and irresolution. I still count on persuading these young people, or enough of them, toward a fearless but not foolish course of action, as some form of revolution seems practically inevitable now, but I fear a hard age of reaction. You would laugh at this, Georg, but I often feel like an old Mephistophelian devil among them. As it is in the nature of youth not to have been able to regularly confront their desire with the world in the battle of life, I try to somehow provide that testing ground for them. I try to test the inner weight of their conviction and to see whether they are inwardly a match for the actions required and for the everyday - the everyday, indeed, after all the mightiest power. I am restless and desperate, and cannot help asking myself: will they be broken when the world, their world, falls apart, or will they be able to persevere in their desire and say, 'nevertheless, in spite of everything' ...

My dearest Georg, I cannot say goodbye to you. What I want to say is,

Forever yours in companionship and friendship

Max

\section{References}

Adair-Toteff C (2005) Sociological Beginnings: The First Conference of the German Society for Sociology. Liverpool: Liverpool University Press.

Lukács G (1986) Selected Correspondence, 1902-1920 (ed J Marcus and Z Tar). New York: Columbia University Press.

Mommsen WJ (1984) Max Weber and German Politics 1890-1920. Chicago, IL: University of Chicago Press.

Mommsen WJ and Osterhammel J (eds) (1987) Max Weber and His Contemporaries. London: Allen \& Unwin. 
Pyyhtinen O (2010) Simmel and 'the Social'. Basingstoke; New York: Palgrave Macmillan.

Scaff LA (1989) Fleeing the Iron Cage: Culture, Politics and Modernity in the Thought of Max Weber. Berkeley, CA: University of California Press.

Simmel G (1995) Aufsätze und Abhandlungen 1901-1908 Band I. In: Von Rüdiger Kramme H, Rammstedt A und Rammstedt O (eds) Georg Simmel Gesamtausgabe Vol. 17. Frankfurt am Main: Suhrkamp Verlag.

Simmel G (1996) Hauptprobleme der Philosophie. In: Kramme R and Rammstedt O (eds) Georg Simmel Gesamtausgabe Vol. 14. Frankfurt am Main: Suhrkamp Verlag.

Simmel G (1999) Der Krieg und die geistigen Entscheidungen; Grundfragen der Soziologie; Vom Wesen des historischen Verstehens; Der Konflikt der modernen Kultur; Lebensanschauung. In: Fitzi G and Rammstedt O (eds) Georg Simmel Gesamtausgabe Vol. 16. Frankfurt am Main: Suhrkamp Verlag.

Simmel G (2001) Aufsätze und Abhandlungen 1909-1918 Band I. In: Von Rüdiger Kramme $\mathrm{H}$ and Rammstedt A (eds) Georg Simmel Gesamtausgabe Vol. 12. Frankfurt am Main: Suhrkamp Verlag.

Simmel G (2004) The Philosophy of Money, 3rd edn. (trans. D Frisby and T Bottomore). London; New York: Routledge.

Simmel G (2005) Briefe 1880-1911. In: Köhnke KC (eds) Georg Simmel Gesamtausgabe Vol. 22. Frankfurt am Main: Suhrkamp Verlag.

Simmel G (2008) Briefe 1912-1918. Jugendbriefe. In: Otthein and Rammstedt A (eds) Georg Simmel Gesamtausgabe Vol. 23. Frankfurt am Main: Suhrkamp Verlag.

Simmel G (2010) The View of Life (trans. J Andrews and D Levine). Chicago, IL: University of Chicago Press.

Swedberg R (2014) The Art of Social Theory. Princeton, NJ; Oxford: Princeton University Press.

Weber M (1924) Gesammelte Aufsätze zur Soziologie und Sozialpolitik (ed M Weber). Tübingen: J.C.B. Mohr (Paul Siebeck).

Weber M (1976) Wirtschaft und Gesellschaft. Grundriss der verstehenden Soziologie (ed J Winckelmann). Tübingen: J.C.B. Mohr (Paul Siebeck).

Weber M (1988a) Gesammelte Aufsätze zur Wissenschaftslehre (ed J Winckelmann). Tübingen: Mohr Siebeck.

Weber M (1988b) Gesammelte Politische Schriften (ed J Winckelmann). Tübingen: Mohr Siebeck.

Weber M (1988c) Max Weber: A Biography. New Brunswick, NJ: Transaction Publishers.

Weber M (1994a) Wissenschaft als Beruf 1917/1919. Politik als Beruf 1919 (MWS I/17) (ed W Mommsen and W Schluchter). Tübingen: Mohr Siebeck.

Weber M (1994b) Political Writings (ed P. Lassman and R Speirs; trans. R Speirs). Cambridge: Cambridge University Press.

Weber M (1994c) Briefe 1909-1910 (MWG II/6) (ed MR Lepsius and WJ Mommsen in collaboration with B Rudhard und M Schön). Tübingen: Mohr Siebeck. 
Weber M (2008) Briefe 1915-1917 (MWG II/9) (ed G Krumeich and MR Lepsius in collaboration with B Rudhard and M Schön). Tübingen: Mohr Siebeck.

Weber M (2012) Briefe 1918-1920 (MWG II/10,1 and II/10,2) (ed G Krumeich and MR Lepsius in collaboration with U Hinz, S OßwaldBargende and M Schön). Tübingen: Mohr Siebeck.

Weber M (2012) Collected Methodological Writings (ed HH Bruun and S Whimster; trans. HH Bruun). London: Routledge.

\section{Author biographies}

Carlos Frade is Senior Lecturer in Sociology at the University of Salford-Manchester. His research is concerned with the renewal of social theory along classical (Machiavellian, Marxian, Weberian) and contemporary (Badiouian) lines; it focuses on the relationship between subjectivity and power and on the possibilities for subjectivation today. He has recently published in journals such as Theory, Culture \& Society, Sociology, Situations, Cosmos and History and Revista Española de Investigaciones Sociológicas.

Olli Pyyhtinen is Professor of Sociology at the University of Tampere, Finland. Broadly put, his research interests lie within social theory, philosophy, science and technology studies, economic sociology, and the study of art. He is the author of the books Simmel and 'the Social' (2010), The Gift and Its Paradoxes (2014) and More-than-Human Sociology (2015), and one of the authors of Disruptive Tourism and Its Untidy Guests (2014; with S. Veijola, J. Germann Molz, E. Höckert and A. Grit). He has also edited the volume The Anthem Compaion to Georg Simmel (2016) together with Thomas Kemple, and his next book, The Simmelian Legacy: A Science of Relations, will be published later this year. 